\title{
Allelopathic inhibition of germination, seedling growth and cell division of selected plant species by Calotropis procera (Ait.) Ait.
}

\author{
Farrukh Hussain ${ }^{* 1}$, Aneela Rasool², Khalid Aziz¹, Sapna Raisham², Sajid Aziz ${ }^{1}$, Lal Badshah² \& Wahid \\ Hussain $^{3}$
}

${ }^{1}$ Institute of Biological Sciences, Sarhad University of Science \& Information Technology, Peshawar, Pakistan

${ }^{2}$ Department of Botany, University of Peshawar, Pakistan

${ }^{3}$ Department of Botany, GPGC Parachinar, Kurram, Pakistan

\section{Article history}

Received: 12 July 2019

Accepted: 08 September 2019

Published: 01 January 2020

\section{Publisher}

Horizon e-Publishing Group

\section{*Correspondence}

Farrukh Hussain

区 farrukh.biotech@suit.edu.pk

\begin{abstract}
Calotropis procera (Ait.) Ait. is perennial medicinal obnoxious shrub growing in Pakistan up to $1500 \mathrm{~m}$ altitude. Hot and water aqueous extracts from leaves and young stems of $C$. procera were used against Pennisetum glaucum (Linn.) R. Br., Setaria italica (Linn.) P. Beauv., Brassica campestris Linn. and Lactuca sativa L. under laboratory condition. It was seen that germination, seedling growth, fresh and dry biomass reduced in concentration dependent manner. It was observed that the allelopathic effects depended upon the tested species, growth parameter measured, soaking duration and concentration of the donor plant material. The $C$. procera litter incorporated into the growth medium inhibited the test species used. The $C$. procera extracts from leaves were more inhibitory than stem extracts. The tendency of inhibition was radical growth $>$ germination $>$ plumule growth suggesting radicle growth to be a better measure of allelopathy. Leaf extracts significantly reduced division and size of cells. It is suggested that aqueous extract from $C$. procera can be further assessed against microbes and weed under laboratory and field condition.
\end{abstract}

Keywords: allelopathy; Calotropis procera; aqueous extracts; seedling growth; inhibited cell division and expansion

Citation: Hussain F, Rasool A, Aziz K, Raisham S, Aziz S, Badshah L, Hussain W. Allelopathic inhibition of germination, seedling growth and cell division of selected plant species by Calotropis procera (Ait.) Ait. Plant Science Today 2020;7(1):1-8. https://doi.org/10.14719/pst.2020.7.1.606

Copyright: (c) Hussain et. al. (2020). This is an open-access article distributed under the terms of the Creative Commons Attribution License, which permits unrestricted use, distribution, and reproduction in any medium, provided the original author and source are credited (https://creativecommons.org/licenses/by/4.0/).

Indexing: Plant Science Today is covered by Scopus, Web of Science, BIOSIS Previews, ESCI, CAS, AGRIS, UGC-CARE, CABI, Google Scholar, etc. Full list at http://www.plantsciencetoday.online

\section{Introduction}

Calotropis procera (Ait.) Ait. (Family Asclepiadaceae) is an erect perennial obnoxious, non-palatable medicinal shrub found up to $1500 \mathrm{~m}$ altitude in drier parts of Pakistan. The nonpalatability to livestock, insects and wild animals facilitates its natural spread. Some evidences regarding the allelopathy of Calotropis species are 
Samreen et al. (1), Abdul-Farid et al. (2), Akinyede et al. (3), Umar et al. (4), Shetta et al. (5) and Hilalul-Zaman \& Ahmad (6), which reported retarded cell division and seedling growth of various tested species.

Allelopathy affects the diversity, functioning and productivity of natural and agroecosystems (7, 8). Lantana (9) and Celtis (10) allelopathically reduced the productivity by affecting various growth parameters of susceptible plants. Raihan et al. (11) reported decreased germination and radical growth of lettuce by extracts from leaves and barks of 145 plant species. Anwar et al. (12) reported the allelopathic nature of papaya leaf extract on various parameters of some weeds. Similarly, Qasem (13) screened 135 plants for their allelopathic capability against the germination and radical growth of wheat. Furthermore, some plants exhibited strong to weak inhibition, while others were stimulatory. Amaranthus retroflexus significantly reduced the stomatal opening, photosynthetic pigments and reduced other growth parameters (14). Li et al., (15) reported that Veronica persica had herbicidal effects against weeds due to presence of 21 compounds in ethanolic extracts. Wu et al. (16) concluded that Eucalyptus significantly retarded germination and early growth of Physalis that can be used as herbicide. The allelopathic effects of leaf, stem and bark of Pistacia were tested against crops and weeds by Tahir et al. (17). They identified 45 compounds from tested parts, which caused inhibition. Similarly, Melia azedarach exhibited strong allelopathy against chick pea and black gram (18). The allelopathic substances responsible for allelopathy were identified.

All these studies suggested that germination, early seedling growth, biochemical and physiological processes were differentially affected. The allelopathic effects usually depended upon donor plant species, test species, parts assayed, concentration and duration of soaking of plant materials. It is also reported that cytological changes and abnormalities in cell division, expansion and chromosomal aberrations occur due to extracts from the donor species.

Since some studies (1-6) on the allelopathy of Calotropis procera are available, therefore the present study further envisaged its allelopathic stress against germination and seedling growth of some common crop species, and its effect on the division and development of cell as a possible allelopathic mechanism. This endeavor can be extended to identify its allelochemicals and phytochemicals responsible for the allelopathy.

\section{Materials and Methods}

Leaves and young stems of mature Calotropis procera were collected at flowering stage from Peshawar University Campus during November,
2017. The plant material was air dried in shade at room temperature $\left(25-30 \quad{ }^{\circ} \mathrm{C}\right)$ and powdered. Glassware, thoroughly washed with tap water, was sterilized at $170{ }^{\circ} \mathrm{C}$ for at least $4 \mathrm{~h}$. Pennisetum glaucum (Linn.) R.Br., Setaria italica (Linn.) P. Beauv., Brassica campestris Linn., Lactuca sativa Linn. and Allium cepa Linn. were used as the test species in the following experiments. The results were statistically analyzed using $t$-test.

\section{Aqueous extract bioassay}

Five gm dried powdered leaves and young stems were separately soaked in $100 \mathrm{ml}$ distilled water at $25{ }^{\circ} \mathrm{C}$ for 24 and $48 \mathrm{~h}$ without stirring; and filtered through Whatman filter paper. These different aqueous extracts were tested against seeds of above mentioned test species on 2-folds of Whatman filter papers in petri dishes. Tests were made by soaking the filter papers with $15 \mathrm{ml}$ each of the extracts. In control extract was replaced with same volume of distilled water. Each treatment was replicated 10 times, each with 10 seeds of test species. Germination, growth of plumule and radicle were measured after $72 \mathrm{~h}$ incubation at $25{ }^{\circ} \mathrm{C}$. Twenty seedlings from test and control treatments were randomly selected for determining fresh and dry weight. Seedlings were dried at $65{ }^{\circ} \mathrm{C}$ for $72 \mathrm{~h}$. Moisture contents were calculated on oven dry basis (19).

For the preparation of hot water extract, $5 \mathrm{~g}$ leaves and stems were separately boiled in $100 \mathrm{ml}$ distilled water for 5 minutes and filtered. These hot-water extracts were cooled to room temperature and tested against the same test species as described above. Although, obtaining hot water extract is an unnatural process because the temperature in nature never rises to boiling point, yet many studies $(7,8,20,21)$ have suggested that not only phytochemicals were resistant but were easily released.

\section{Effect of litter}

\section{Litter bed bioassay}

Five gm powdered leaf and stem litter of $C$. procera were uniformly spread in a petri dish and topped with a single sheet of filter paper. In control, litter was replaced with $5 \mathrm{gm}$ fine pieces of filter papers. All the dishes were provided with 20 $\mathrm{ml}$ distilled water, which were considered optimal moisture. After $6 \mathrm{hr}$, seeds of the test species were placed on the top of filter paper. There were 10 replicates, each with 10 seeds in each of the treatments. The petri dishes were incubated as before and the same parameters were measured.

\section{Pot experiment}

The effect of litter was further tested by placing 5 gm crushed leaf litter in small plastic pots (measuring 6x9 $\mathrm{cm}$ tapering down to $6 \mathrm{~cm}$ ) containing equal volume of coarse sand, which had been sterilized at $170{ }^{\circ} \mathrm{C}$ for $4 \mathrm{~h}$. For each 
treatment five replicates, each with 10 seeds were made. Control treatment consisted of same weight of fine pieces of filter papers. These pots were incubated at $25{ }^{\circ} \mathrm{C}$ in dark. All the pots were irrigated wit $25 \mathrm{ml}$ Hoagland nutrient solution (22). Germination was recorded after $72 \mathrm{~h}$ and thereafter, the pots were shifted to partial shady condition (veranda). Seedling growth was noted after 15 days, which was sufficient time to show the differences in the test and control treatments.

\section{Rain leachate bioassay}

Natural rain leachates were collected from crushed leaves following Hussain et al. (8) during spring rains. The original rain leachates were dilute; therefore they were concentrated to $50 \%$ (highly concentrated) and 25\% (less concentrated) of original concentration in rotavapor. These three concentrations (original, 50\%, 25\%) of rain leachates were tested against seeds and seedling growth of $L$. sativa and A. cepa in aqueous extract bioassay as above.

\section{Effect on cell development (Cell size and cell area)}

Plant extract from leaves and stem-barks, prepared by soaking $5 \mathrm{~g}$ materials in $100 \mathrm{ml}$ distilled water for $48 \mathrm{~h}$, were tested as before against seeds of $P$. glaucum, $S$. italica, $L$. sativa and
A. cepa in standard filter paper bioassay using distilled water as control. After $72 \mathrm{~h}$ incubation at $25{ }^{\circ} \mathrm{C}$, the radicle tips were excised and placed in concentrated solution of chloral hydrate. After 10$12 \mathrm{hr}$, the tips were randomly taken out, placed on plain microscopic glass slide under cover slip and gently pressed to spread the material in a thin layer. The size of cells was measured between 3rd to 5th cortical layers in a row over fixed distance. Ten tips, each with 5 counts, were observed.

\section{Effect on cell division}

Radicle-tips from the preceding aqueous extract bioassay were saved; and fixed in Carnoy's fixer (mixture of absolute alcohol: glacial acetic acid, 3:1) for $12 \mathrm{~h}$. These tips were then thoroughly washed with distilled water and saved in $70 \%$ alcohol at $5-10{ }^{\circ} \mathrm{C}$. The meristematic tips were hydrolyzed in $I N \mathrm{HCI}$ at $60{ }^{\circ} \mathrm{C}$ for 10 to $15 \mathrm{~min}$. $\mathrm{HCl}$ was thoroughly washed with distilled water and fixed in basic fuchsine in airtight vials in dark. Within 30 min the tips turned violet. A single roottip was placed in 2-3 drops of aceto-carmine on a slide and slightly warmed. The cover slip was gently pressed to disperse the tissue. This temporary slide was used for counting dividing/non-dividing cells under microscope with 100x magnification (Olumpus, XC-401 A, Shinjuku Monalith, Nish Shinjuku, Tokyo, Japan).

Table 1. Effect of aqueous extracts of Calotropis procera on the germination and various growth parameters of test species.

\begin{tabular}{|c|c|c|c|c|c|c|c|c|c|c|c|c|}
\hline \multirow[b]{2}{*}{ Test species } & \multirow[b]{2}{*}{ Control } & \multirow[b]{2}{*}{$\begin{array}{l}\text { Soaking } \\
\text { time (h) }\end{array}$} & \multicolumn{10}{|c|}{ Extracts } \\
\hline & & & Leaves & $\begin{array}{c}\% \text { of } \\
\text { control }\end{array}$ & Stems & $\begin{array}{c}\% \text { of } \\
\text { control }\end{array}$ & Control & $\begin{array}{l}\text { Soaking } \\
\text { Time (h) }\end{array}$ & Leaves & $\begin{array}{c}\% \text { of } \\
\text { control }\end{array}$ & Stems & $\begin{array}{c}\% \text { of } \\
\text { control }\end{array}$ \\
\hline \multicolumn{7}{|c|}{ Germination (\%) } & \multicolumn{6}{|c|}{ Fresh weight (mg) } \\
\hline \multirow{2}{*}{$\begin{array}{l}\text { Pennisetum } \\
\text { glaucum }\end{array}$} & \multirow{2}{*}{67} & 24 & $12^{*}$ & 18.4 & 22 & 32.8 & 690 & 24 & 370 & $53.6^{*}$ & 330 & $47.8^{*}$ \\
\hline & & 48 & $15^{*}$ & 22.4 & 33 & 49.3 & & 48 & 310 & $44.9 *$ & 320 & $46.4^{*}$ \\
\hline \multirow{2}{*}{ Setaria italica } & \multirow{2}{*}{85} & 24 & $61^{*}$ & 71.8 & 74 & 87.0 & 960 & 24 & 400 & $41.7^{*}$ & 400 & $41.7^{*}$ \\
\hline & & 48 & $63^{*}$ & 74 & 68 & 80.0 & & 48 & 400 & $41.7^{*}$ & 800 & $83.3^{*}$ \\
\hline \multirow{2}{*}{$\begin{array}{l}\text { Brassica } \\
\text { campestris }\end{array}$} & \multirow{2}{*}{78} & 24 & $45^{*}$ & 57.7 & 60 & 76.9 & 450 & 24 & 350 & $77.8^{*}$ & 270 & $60.0^{*}$ \\
\hline & & 48 & $34^{*}$ & 43.6 & 50 & 64.0 & & 48 & 270 & $60.0^{*}$ & 250 & $55.6^{*}$ \\
\hline \multicolumn{7}{|c|}{ Radicle Growth (mm) } & \multicolumn{6}{|c|}{ Dry weight (mg) } \\
\hline \multirow{2}{*}{$\begin{array}{l}\text { Pennisetum } \\
\text { glaucum }\end{array}$} & \multirow{2}{*}{23.2} & 24 & $12.2^{*}$ & 53.6 & $10.1^{*}$ & 43.5 & 180 & 24 & 170 & 94.4 & 170 & 94.4 \\
\hline & & 48 & $9.0^{* *}$ & 38.8 & 12.0 & 51.7 & & 48 & 130 & $72.2^{*}$ & 130 & $72.2^{*}$ \\
\hline \multirow{2}{*}{ Setaria italica } & \multirow{2}{*}{10.7} & 24 & $6.4^{*}$ & 59.8 & 5.30 & 50 & 400 & 24 & 110 & 27.5 & 110 & 27.5 \\
\hline & & 48 & $4^{* *}$ & 37.4 & $7.4^{* *}$ & 69.2 & & 48 & 100 & $25.0^{*}$ & 300 & 75.0 \\
\hline \multirow{2}{*}{$\begin{array}{l}\text { Brassica } \\
\text { campestris }\end{array}$} & \multirow{2}{*}{13.9} & 24 & $6.4^{* *}$ & 46.0 & 8.8 & 63.3 & 80 & 24 & 70 & 87.5 & 70 & 87.5 \\
\hline & & 48 & $2.1^{* *}$ & 15.1 & 9.1 & 65.5 & & 48 & 70 & 87.5 & 75 & 93.8 \\
\hline \multicolumn{7}{|c|}{ Plumule Growth (mm) } & \multicolumn{6}{|c|}{ Moisture contents (\%) } \\
\hline \multirow{2}{*}{$\begin{array}{l}\text { Pennisetum } \\
\text { glaucum }\end{array}$} & \multirow{2}{*}{6.7} & 24 & $2.3^{* *}$ & 34.3 & 2.3 & 34.3 & 283 & 24 & 117 & $41.3^{*}$ & 94 & $33.2^{*}$ \\
\hline & & 48 & $1.8^{* *}$ & 26.9 & 1.34 & 19.4 & & 48 & 146 & $51.6^{*}$ & 138 & $48.8^{*}$ \\
\hline \multirow{2}{*}{ Setaria italica } & \multirow{2}{*}{8.5} & 24 & $1.80^{* *}$ & 21.2 & $3.60^{* *}$ & 42.4 & 425 & 24 & 207 & $48.7^{*}$ & 72 & $17^{*}$ \\
\hline & & 48 & $1.40^{* *}$ & 16.5 & $2.10^{* *}$ & 24.7 & & 48 & 290 & $68.2^{*}$ & 33 & $7.8^{*}$ \\
\hline \multirow{2}{*}{$\begin{array}{l}\text { Brassica } \\
\text { campestris }\end{array}$} & \multirow{2}{*}{7.8} & 24 & $2.60^{* *}$ & 33.3 & $2.60^{* *}$ & 33.3 & 462 & 24 & 337 & $72.9^{*}$ & 285 & $61.7^{*}$ \\
\hline & & 48 & $1.90^{* *}$ & 24.4 & $2.00 * *$ & 25.6 & & 48 & 285 & $61.7^{*}$ & 212 & $45.9^{*}$ \\
\hline
\end{tabular}

Each value is a mean of 10 replicates, each with 10 seeds. *and ** Significantly different from control at $P=0.05$ and at $P=0.01$ 
Table 2. Effect of Hot water extracts on the germination (\%) and various growth parameters of test species.

\begin{tabular}{|c|c|c|c|c|c|c|c|c|c|c|}
\hline \multirow{2}{*}{ Test species } & \multirow{2}{*}{ Control } & \multicolumn{9}{|c|}{ Extracts } \\
\hline & & Leaves & $\begin{array}{c}\% \text { of } \\
\text { control }\end{array}$ & Stems & $\begin{array}{c}\% \text { of } \\
\text { control }\end{array}$ & Control & Leaves & $\begin{array}{c}\% \text { of } \\
\text { control }\end{array}$ & Stems & $\begin{array}{c}\% \text { of } \\
\text { control }\end{array}$ \\
\hline \multicolumn{6}{|c|}{ Germination } & \multicolumn{5}{|c|}{ Fresh weight (mg) } \\
\hline Pennisetum glaucum & 67 & $5^{* *}$ & 75 & $13^{* *}$ & 19.4 & 690 & 240 & $34.8^{*}$ & 310 & $44.9 *$ \\
\hline Setaria italica & 85 & $62^{*}$ & 72.9 & $62^{*}$ & 72.9 & 900 & 480 & $53.3^{*}$ & 500 & $55.6^{*}$ \\
\hline Brassica campestris & 78 & $43^{*}$ & 55.1 & $58^{*}$ & 74.4 & 450 & 330 & $73.3^{*}$ & 280 & $62.2^{*}$ \\
\hline Lactuca sativa & 98 & $50^{*}$ & 51.0 & $62^{*}$ & 63.3 & 550 & 307 & $55.8^{*}$ & 377 & 68.6 \\
\hline \multicolumn{6}{|c|}{ Radicle Growth (mm) } & \multicolumn{5}{|c|}{ Dry Weight (mg) } \\
\hline Pennisetum glaucum & 23.2 & $8.1^{*}$ & 34.9 & $9.0^{*}$ & 38.8 & 180 & 150 & 83.3 & 150 & 83.3 \\
\hline Setaria italica & 10.7 & $5.5^{* *}$ & 51.4 & $6.2^{* *}$ & 57.9 & 400 & 170 & 42.5 & 180 & 45.0 \\
\hline Brassica campestris & 13.9 & $4.4^{* *}$ & 31.7 & $9.2^{* *}$ & 66.2 & 80 & 70 & 87.5 & 70 & 87.5 \\
\hline Lactuca sativa & 7.0 & 3.0 & 42.2 & 3.0 & 42.7 & 319 & 195 & 61.2 & 200 & 52.7 \\
\hline \multicolumn{6}{|c|}{ Plumule Growth (mm) } & \multicolumn{5}{|c|}{ Moisture contents (\%) } \\
\hline Pennisetum glaucum & 5.6 & $1.8^{* *}$ & 32.1 & 1.5 & 26.7 & 283 & 60 & $21.5^{*}$ & $106^{*}$ & 37.5 \\
\hline Setaria italica & 3.8 & $2^{* *}$ & 52.6 & $2.2^{* *}$ & 57.9 & 125 & 182 & $146^{*}$ & 117 & 93.6 \\
\hline Brassica campestris & 3.1 & $2.3^{* *}$ & 74.92 & $2.0^{* *}$ & 64.5 & 462 & 371 & 80.3 & 300 & 64.9 \\
\hline Lactuca sativa & 8.5 & 5.0 & 58.2 & 6.0 & 70.0 & 72.4 & 57.4 & 79.3 & 88.5 & 122.2 \\
\hline
\end{tabular}

Each value is a mean of 10 replicates, each with 10 seeds. * and ** Significantly different from control at $P=0.05$ and at $P=0.01$

\section{Results and Discussion}

\section{Aqueous extract bioassay}

The aqueous extracts from leaves and stems of $C$. procera significantly inhibited the germination, radicle and plumule growth of all the test species in various treatments (Table 1). Extracts from leaves in this case were more inhibitory than stems. Higher soaking duration ( $48 \mathrm{~h}$ ) was found to have a greater inhibitory effect than shorter duration $(24 \mathrm{~h})$. The fresh weight of all the test species declined under test condition, especially in leaves (Table 1). The dry weight of S. italica significantly declined in leaf and stem extracts, that of $B$. campestris slightly reduced in test condition. $P$. glaucum remained unaffected in $24 \mathrm{~h}$ extract (Table 1). Moisture contents of all the tested species declined in all the treatments. The $48 \mathrm{~h}$ extracts from leaves were strongly inhibitory than stem extracts. The present findings are in line with those of Raihan et al. (11), BakhshayeshanAgdam et al. (14) and Thakur et al. (18), who also observed similar allelopathic effects in their studies. Hussain \& Ilahi (7) and Hussain et al. (8) reported that leaf extracts of Cenchrus and Bothriochloa strongly inhibited the germination than stem and root extracts. The findings regarding differential phytotoxicity agree with contemporary workers. For example, Raihan et al. (11) observed that extracts from bark and leaves of donor species differentially inhibited the test species. The response of wheat and cucumber towards extracts from Amaranthus varied (14). Li et al. (15) concluded that various weed species responded differently to Veronica extracts. Similarly, the allelopathic inhibition depended upon the test species, parts of plant used for extraction, concentration and parameters measured as reported in many studies $(12,13,17$, 23-25). All these studies are in line with the present findings. Hot water extracts diminished the germination, radicle and plumule growth (Table 2 ), and fresh weight (Table 2) of tested species in all the treatments. The moisture contents of $P$. glaucum and $B$. campestris in leaf and stem extracts and that of $L$. sativa in leaf extract declined. The moisture contents of $S$. italica growing in leaf extract enhanced; but in stem extract there was no effect. The stem extract enhanced the moisture contents of $L$. italica. Hot water extracts from leaves exhibited strong inhibition than stem extracts. Lodhi \& Nickell (20) also stated that hot water extracts from Celtis reduced gas exchange capacity and moisture contents of test seedlings. The results are also in line with those of Hussain \& Ilahi (7) and Hussain et al., $(8,21)$ who reported that hot water extracts from shoots of Cenchrus and Bothriochloa decreased germination and various growth parameters of tested seedlings.

\section{Effect of litter}

Addition of plant litter generally improves fertility and soil condition, but, litter from many plants intoxicates the immediate habitat by releasing water soluble phytotoxins. In the present case, in litter bed bioassay the added Calotropis litter 
Table 3. Effect of Calotropis procera litter on the germination and growth parameters of test species.

\begin{tabular}{|c|c|c|c|c|c|c|c|c|c|c|}
\hline \multirow[b]{2}{*}{ Test species } & \multirow[b]{2}{*}{ Control } & \multicolumn{9}{|c|}{ Litter } \\
\hline & & Leaves & $\begin{array}{c}\% \text { of } \\
\text { control }\end{array}$ & Stems & $\begin{array}{c}\% \text { of } \\
\text { control }\end{array}$ & Control & Leaves & $\begin{array}{c}\% \text { of } \\
\text { control }\end{array}$ & Stems & $\begin{array}{c}\% \text { of } \\
\text { control }\end{array}$ \\
\hline \multicolumn{6}{|c|}{ Germination } & \multicolumn{5}{|c|}{ Fresh weight (mg) } \\
\hline Pennisetum glaucum & 35 & $2^{*}$ & 5.7 & $7^{*}$ & 20 & 100 & 20 & $20^{*}$ & 30 & $30 *$ \\
\hline Setaria italica & 31 & $16^{*}$ & 51.6 & $20^{*}$ & 64.5 & 100 & 40 & $40^{*}$ & 50 & $50^{*}$ \\
\hline Brassica campestris & 43 & $30^{*}$ & 69.7 & $31.8^{*}$ & 74 & 100 & 51 & $51^{*}$ & 55 & $55^{*}$ \\
\hline Lactuca sativa & 85 & $53^{*}$ & 62.4 & $57^{*}$ & 67 & 495 & 379 & 76.6 & 361 & 72.9 \\
\hline \multicolumn{4}{|c|}{ Radicle Growth (mm) } & & & \multicolumn{5}{|c|}{ Dry Weight (mg) } \\
\hline Pennisetum glaucum & 21.4 & $7^{*}$ & 32.7 & $6.2^{*}$ & 29 & 50 & 10 & $20^{*}$ & 10 & $20^{*}$ \\
\hline Setaria italica & 48.2 & $2.8^{*}$ & 5.8 & $9.7^{*}$ & 20.1 & 70 & 30 & $42.9 *$ & 40 & $57^{*}$ \\
\hline Brassica campestris & 22 & $4.2^{*}$ & 19.0 & $6.2^{* *}$ & 28.2 & 65 & 31 & $47.7^{*}$ & 43 & $66.2^{*}$ \\
\hline Lactuca sativa & 5.9 & 2.1 & 35.8 & 3.0 & 47.5 & 392 & 350 & 89.3 & 310 & 79.8 \\
\hline \multicolumn{4}{|c|}{ Plumule Growth (mm) } & & & \multicolumn{5}{|c|}{ Moisture contents (\%) } \\
\hline Pennisetum glaucum & 4.7 & $1.5^{*}$ & 31.9 & $2.1^{*}$ & 44.7 & 100 & 100 & 100 & 200 & $200^{*}$ \\
\hline Setaria italica & 23.8 & $7.7^{*}$ & 32.4 & $8.1^{*}$ & 34.0 & 42 & $33^{*}$ & 78.6 & 25 & $59.5^{*}$ \\
\hline Brassica campestris & 17.2 & $1.2^{*}$ & 7.0 & $2.5^{* *}$ & 14.5 & 53 & 64 & 120 & 27 & $50.9^{*}$ \\
\hline Lactuca sativa & 6.8 & 5.6 & 82.8 & 5.7 & 84.6 & 26.3 & 8.3 & 31.6 & 16.5 & 62.6 \\
\hline
\end{tabular}

Each value is a mean of 5 replicates, each with 10 seeds. * and ** Significantly different from control at $P=0.05$ and at $P=0.01$

suppressed the germination, radicle and plumule growth of various test species (Table 3). The fresh and dry weight of $P$. glaucum, B. campestris, $S$. italica and $L$. sativa reduced significantly in all the treatments (Table 3). The moisture contents of $S$. italica and L. sativa reduced in both the extracts and that of B. campestris declined in stem extracts; but gained moisture in leaf extracts. Moisture contents of $P$. glaucum remained unaffected by leaf extract but were enhanced by stem extract (Table 6). In pot experiment, the incorporated litter reduced the germination, height, fresh and dry weight of all the tested species (Table 4). The moisture contents of $S$. italica and $L$. sativa decreased in both the treatments; while the moisture contents of $P$. glaucum and B. campestris increased. However, Premathilake et al. (26) and Thakur et al. (27) observed that incorporated litter was not harmful to the test species in pot experiments. Kluthe et al. (28) reported phytotoxicity of litter that supports the present findings.

\section{Rain leachate bioassay}

The results of preceding experiments were further confirmed by the phytotoxicity of natural rain leachates against $L$. italica and A. sativa (Table 5 ). The original concentration of rain leachates was low to inhibit germination, plumule and radical growth; but $50 \%$ and $25 \%$ concentrated extracts significantly diminished germination and radical growth of both the test species. The order of inhibition was: $50 \%>25 \%>$ original rain leachate concentration. The inhibitory effects were due to release of some phytochemicals from Calotropis. Although, we did not isolated phytochemicals in this study, yet many other studies have identified phytochemicals responsible for allelopathy by Calotropis. Alkaloids, tannins, flavonoides, phenolic compounds, saponins, glycosides and many other phytochemicals have been reported (4, $6,29-31)$. We expect that allelopathy is operative through these phytochemicals in the present case. In nature, litter soaked by rain or moist soil releases various phytochemicals similar to the present effort thereby intoxicating the immediate soil. The phytotoxicity of rain leachates was concentration dependent, species tested and parameters measured. The released phytotoxins accumulate to physiologically active concentration in the habitat that adversely affects the associated species, thereby supporting the present findings.

\section{Effect on division and growth of cell}

Allelochemicals cause death, blistering and growth inhibition of cell. Adverse biochemical changes and decreased chlorophyll contents within the plant body decreases uptake of water and nutrients. This leads to limited growth, biological, physiological and cytological functions of susceptible plants. It was demonstrated that leaf extracts not only significantly reduced cell division (Table 6), but also lessened the cell size and development. The dividing cells were $38 \%, 35.8 \%$, $24.5 \%$ and $25.1 \%$ respectively in $P$. glaucum, $S$. italica, B. campestris and A. cepa. Similarly, the size of cell decreased in test condition. This is one of mechanisms for limiting radicle and shoot growth. The findings concur with those of Santosa et al. (32), Hussain et. al. $(33,34)$ and Hussain \& Ilahi (7), who affirmed that aqueous extracts of Kielemeyra, Eragrostis and Cenchrus reduced both the division and development of cells. Cheng et al. (35) stated that low concentration of 
Table 4. Effect of added litter (Mulch) of Calotropis procera on the germination (\%) and various growth parameters seedling of test species in pot experiment.

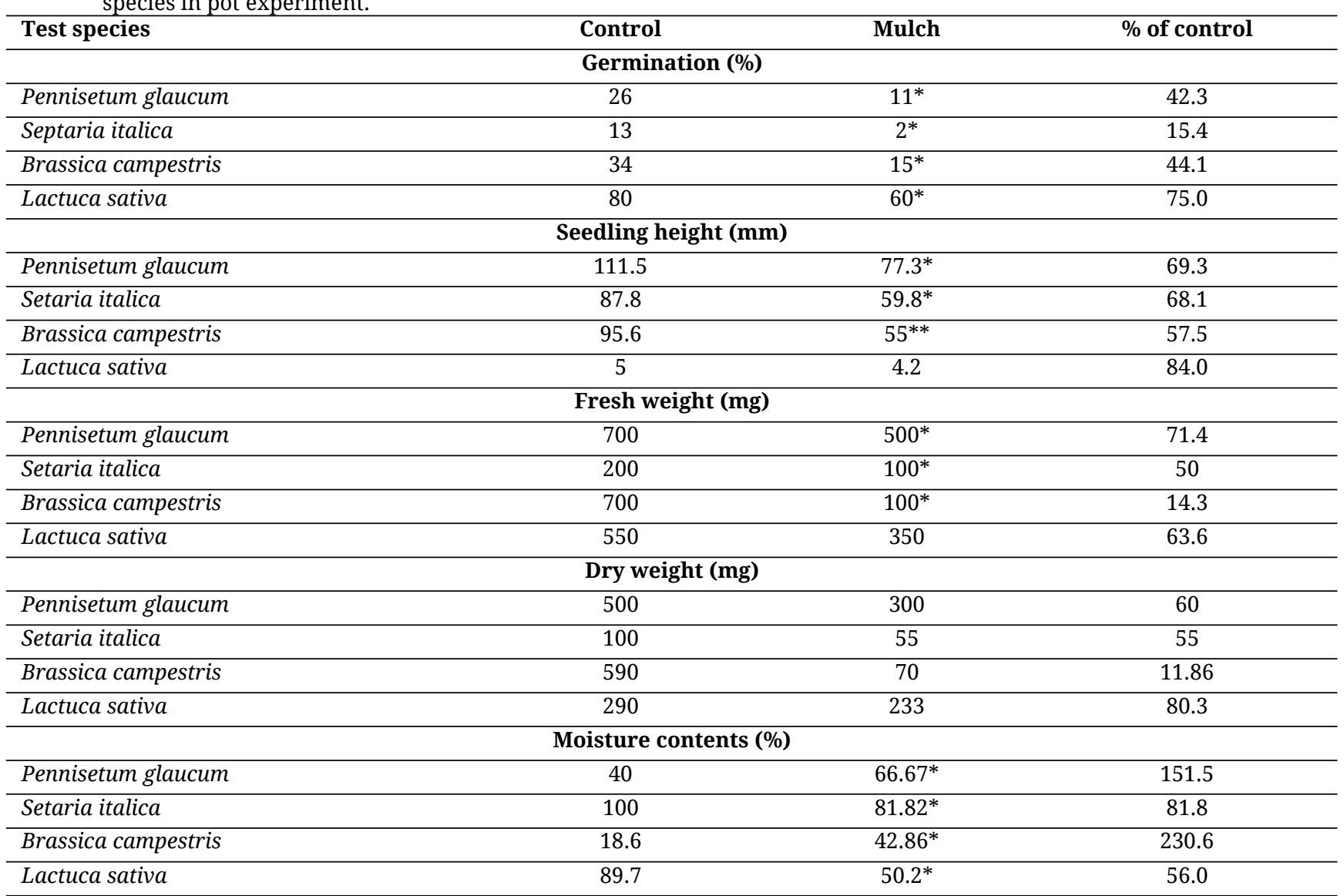

Germination is a mean of 5 replicates, each with 10 seeds; others mean of 5 replicates each with 2 seedlings.

*Significantly different from control at $P=0.05$

allelochemicals from garlic promoted the cell length but higher concentration reduced these activities. Likewise, Chaudhuri et al. (36) observed reduced nuclear volume and increased interphase chromatin material. Raoof \& Siddiqui (37), Santosa et al., (32) and Irum et al. (38) stated that various phytochemicals causing allelopathic stress reduce growth and productivity. The decreased cell division and growth by allelopathic stress is reported in many studies $(23,39-43)$. However, Fonseca et al. (44) reported no effect on mitotic index and cell division by Schinus leaf extracts. The presence of various phytochemicals $(3,6,45)$ in Calotropis procera can be responsible for its observed allelopathy. The findings of Lubini $e t$ al. (46), Sharma et al. (47) and Abdelmigid \& Morsi (48) support the present results with respect to inhibition of cell division.

The present findings conclude that Calotropis procera is strongly allelopathic at least against the tested species. The allelopathic effects depended upon the parts of Calotropis used in

Table 5. Effect of rain leachates from Calotropis procera leaves on the germination and radicle growth of Lactuca sativa and Allium cepa.

\begin{tabular}{cccccc}
\hline Species & Parameter & Control & $\begin{array}{c}\text { Original low } \\
\text { concentration rain } \\
\text { leachates }\end{array}$ & $\begin{array}{c}\text { 25\% concentrated } \\
\text { rain leachates }\end{array}$ & $\begin{array}{c}\mathbf{5 0 \%} \text { (Strongly) } \\
\text { concentrated rain } \\
\text { leachates }\end{array}$ \\
\hline Lactuca sativa & Germination & 100 & $90(90 \%)$ & $75(75 \%)$ & $45(45 \%)$ \\
\hline Allium cepa & Radicle Growth & 25.9 & $20.2(77.99 \%)$ & $15.35(59.27 \%)$ & $10.92(42.16)$ \\
\hline & Germination & 86 & $79(91.86 \%)$ & $62(72.09 \%)$ & $49(55.06 \%)$ \\
\hline
\end{tabular}

Table 6. Effect of Calotropis procera leaf extract on the division and size of cells of test species.

\begin{tabular}{lccc}
\hline \multicolumn{1}{c}{ Species } & $\begin{array}{c}\text { No. of Dividing cells in } \\
\text { Control }\end{array}$ & $\begin{array}{c}\text { No. of Dividing cells in Lest } \\
\text { extract }\end{array}$ & \% of Control \\
\hline Pennisetum glaucum & 250 & $95^{*}$ & 38.0 \\
\hline Setaria italica & 279 & $100^{*}$ & 35.8 \\
\hline Brassica campestris & 200 & $49^{*}$ & 24.5 \\
\hline Allium cepa & 311 & $78^{*}$ & 25.1 \\
\hline & & Cell Sizes, $\boldsymbol{\mu}$ & \\
\hline Pennisetum glaucum & 26.2 & $16.92^{*}$ & 64.58 \\
\hline Setaria italica & 17.5 & $9.22^{*}$ & 52.69 \\
\hline Brassica campestris & 22.9 & $8.25^{*}$ & 36.03 \\
\hline Allium cepa & 30.0 & $12.92^{*}$ & 43.07 \\
\hline
\end{tabular}


bioassays, the response of receptor (test) species and the growth parameter determined. It was observed that germination, seedling growth, fresh and dry mass and moisture contents of various test species responded independently. Further studies are needed to identify the possible allelochemicals and search for their use as alternative herbicides and insecticides.

\section{Acknowledgements}

The authors are grateful to the Lab Staff of Department of Botany, University of Peshawar for their assistance.

\section{Authors' contributions}

All the authors contributed equally to the work presented in this paper.

\section{Competing Interests}

The authors declared that they have no conflict of interest.

\section{References}

1. Samreen U, Hussain F, Sher Z. Allelopathic potential of Calotropis procera (Ait.) Ait. Pak. J Pl Sci 2009;15(1):7-14

2. Abdul-Farid I, Magdi El-Syed, Eman M. Allelopathic potential of Calotropis procera and Morettia philaeana. Int J Agric \& Biol 2013;15(1):130

3. Akindele PO, Fatunla OA, Ibrahim KA, Afolayan CO. Antibacterial and phytochemical screening of Calotropis procera leaf extracts against vancomycin and methicillin resistant bacteria isolated from wound samples in hospital patients. Jour Complem \& Alternative $\quad$ Med Res 2017; 2(1):1-14 https://doi.org/10.9734/JOCAMR/2017/30975

4. Umar S, Shuaib NH, Dangore II, Hassan KY. Evaluation of allelopathic effects of Calotropis procera on sorghum and maize. Standard Sci Res Essays 2014; 2(8):345-49.

5. Shetta ND, Alshahrani TS, Aref IM, Nasser R.A. Allelopathic potential of Calotropis procera and Eucalyptus species on germination and growth of some timber trees. Allelopathy Journal 2017; 40(1):81-94. https://doi.org/10.26651/2017-40-1-1068

6. Hilal-Ul-Zaman, Ahmad S. Antibacterial activity and phytochemical analysis of leaf extracts of Calotropis procera. Acta Scientific Pharmaceu Sci 2017; 1.5 (2017):1921.

7. Hussain F, Ilahi I. Allelopathic potential of Cenchrus ciliaris L. and Bothriochloa pertusa (L) A. Camus. J Sci \& Technol 2009; 33(1\&2): 47-55

8. Hussain F. Ilahi I, Malik SA, Dasti AA, Ahmad B. Allelopathic effects of rain leachates and root exudates of Cenchrus ciliaris L and Bothriochloa pertusa (L) A. Camus. Pak J Bot 2011; 43(1): 341-50.

9. Saxena MK. Aqueous leachate of Lantana camara kills water hyacinth. J. Chem. Ecol 2000; 26(10):2435-48. https:// doi.org/10.1023/A:1005539230307

10. Ahmad I, Hussain F, Barkatullah, Ahmad B. Phytotoxic potential of Celtis australis L. (Family Ulmaceae) against four crop species. Pak J Bot 2014;46(6):2063-67.

11. Raihan I, Miiyaural R, Baki BB. Fujii Y. Assessment of allelopathic potential of goniothalamin allelochemicals from Malyasian plant Goniothalamus andersonii J. Sncclair by sandwich method. Allelopathy Journal
2019;46(1):25-40. https://doi.org/10.26651/allelo.j/2019-46$\underline{1-1196}$

12. Anwar T, Ilyas N, Qureshi R, Malik M. A. Allelopathic potential of Carica papaya against selected weeds of wheat crop. Pak J Bot 2019; 51(1):279-87. https://doi.org/10.30848/PJB2019-1(37)

13. Qasem JR. A survey of the phytotoxicity of common weeds, wild grown species and medicinal plants on wheat. Allelopathy Journal 2017;42(2):179-94 https://doi.org/10.26651/allelo.j./2017-42-2-1115

14. Bakhshayeshan-Agdam H, Salehi-Lisar SY, Motafakkerazad R. Allelopathic effects of redroot pigweed (Amaranthus retroflexus $\mathrm{L}$ ) aqueous extract on cucumber and wheat. Allelopathy Journal 2019; 46(1):55-72. https://doi.org/10.26651/allelo.j/2019-46-1-1198

15. Li ZR, LiuYB, Zhou XM, Li XG, Bai LY. Allelopathic herbicidal effects of crude ethanolic extracts of Veronica persica (Lour) Merr. on weeds. Allelopathy Journal 2019; 46(1):85-96. https://doi.org/10.26651/allelo.j/2019-46-1$\underline{1200}$

16. Wu H, Lin JM, Zhang JB. Allelopathic effects of Eucalyptus salubris F. Muell. and E. brockwayii C.A. Gardner on germination and seedling growth of prairie ground cherry (Physalis hederifolia A. Gray). Allelopathy Journal 2019; 46(1):109-20. https://doi.org/10.26651/allelo.j/2019-46-1$\underline{1202}$

17. Tahir NA, Azeez HA, Hama-Amin HH, Rashid JS, Omer DA. Antibacterial activity and allelopathic effects of extracts from leaf, stem and bark of Mt. Atlas mastic tree (Pistacia atlantica subsp kurdica) on crops and weeds. Allelopathy Journal 2019; 46(1):121-32. https://doi.org/10.26651/allelo.j/2019-46-1-1203

18. Thakur NS, Kumar D, Chauhan RS, Hedge HT, Gunaga RP. Allelopathic effects of Melia azedarach L on germination, growth and yield of black gram and chickpea. Allelopathy Journal 2019; 46(1):133-44 https://doi.org/10.26651/allelo.j/2019-46-1-1204

19. Hussain F. Field and Laboratory Manual of Plant Ecology. 1989; University Grants Commission, Islamabad.

20. Lodhi MAK, Nickell GI. Effects of leaf litter of Celtis laevigata on growth, water contents, and carbon dioxide exchange rates of three grass species. Bull Torrey Bot Club 1973; 100:59-165. https://doi.org/10.2307/2484627

21. Hussain F, Ahmad B, Illahi I. Allelopathic effects of Cenchrus ciliaris L and Bothriochloa pertusa (L) A. Camus. Pak. J. Bot 2010; 42(5): 3587-3604.

22. Hoagland DR, Arnon DI. The water-culture method of growing plants without soil. Calif Agr Expt Sta Circ 347. 1950.

23. Bassey CS, Okoi EP. Comparative evaluation of the allelopathic effects of the leaf extracts of three Asteraceae species (Ageratum conyzoides, Vernonia amygdalina, Artemisia annua). Archives of Current Research International 2018; 15(3):1-8. https://doi.org/10.9734/ACRI/ 2018/45397

24. Gulzar A, Siddiqui MB. Allelopathic effects of Calotropis procera (Ait.) R. Br. on growth and antioxidant activity of Brassica oleracea var botrytis. Jour Suadi Soc Agric Science 2017; 16:375-82. https://doi.org/10.1016/j.jssas.2015.12.003

25. Manzoor SA, Zubair M, Hussain SB, Akhtar SNR, Nouman W. Evaluation of allelopathic effects of Calotropis procera against wheat (Triticum aestivum) using seedling rigor and germination indices. J Biodiver \& Environ Sci 2013;3(5):25-30.

26. Premathilake UGAT, Wathugalal DL, Dharmadasa RM. Phytotoxic potential of lemon grass (Cymbopogon citrates (DC) Stapf. Allelopathy Journal 2018; 45(2):261-68. https://doi.org/10.26651/allelo.j./2018-44-2-1168

27. Thakur NS, Parmar AG, Gunaga RP, Patel DP. Allelopathic influence of leaf and leaf litter of white cedar (Melia azedarach L.) on eggplant and okra. Allelopathy Journal 2017; 42(2):295-306. https://doi.org/10.26651/allelo.j./201742-2-1124 
28. Kluthe BG, Ali MBHB, Stephenson SL. Allelopathic influence of Eucalyptus on common Kenyan agricultural crops. J Agron Agric Sci 2018;1(1):2-6.

29. Chandrawat P, Sharma RA. The genus Calotropis: An overview on bioactive principles and their biosafety. Res J Recent Sci 2016;5(1):61-70.

30. Gulzar A, Siddiqui MB, Bi S. Phenolic acid allelochemicals induced morphological, ultrastructural, and cytological modification on Cassia sophora L. and Allium cepa L. Protoplasma 2016;253(5):1211-21. https://doi.org/10.1007/s00709-015-0862-x

31. Waheed N, Jabeen K, Iqbal S, Javid A. Biopesticidal activity of Calotropis procera against Macrophomina phaseolina. African J Tradit Complement \& Altern Med 2016;13(6):163167. https://doi.org/10.21010/ajtcam.v13i6.23

32. Santos VHMde, Daneluzzi GS, Silva LP, da Silva RMG. Evaluation of allelopathic potential of leaf extracts of Kielmeyera coriacea on Lactuca sativa L. Biosci J.2015; 31(1): 259-67. https://doi.org/10.14393/BJ-v31n1a201517662

33. Hussain F, Zaidi MI, Chughtai SR. Allelopathic effects of Pakistani Weeds: Eragrostis poaeoides P. Beauv. Pak J Sci Ind Res 1984;27:159-64.

34. Hussain F, Abidi N, Malik ZH. Imperata cylindrica affects germination, early growth and cell division and development in some crop species. Pak J Sci Ind Res 1994; 37:100-03.

35. Cheng F, Cheng Z, Meng $\mathrm{H}$, Tang $\mathrm{X}$. The garlic allelochemicals diallyl disulfide affects tomato root growth by influencing cell division, phytohormone balance and expansion gene expression. Front Plant Sci 2016;7:1199. https://doi.org/10.3389/fpls.2016.01199

36. Chaudhuri A, Kundu LM, Datta S, Chatterjee S, Goswami S, Roy GC et al. Allelopathic effects of aerial parts aqueous extract of Amelocissus latifolia (Roxb) Planch. in apical meristem cells. Asian J. Plant Sci. Res 2015;5(3):11-16.

37. Raoof KM, Siddiqui MB. Allelotoxic effect of parthenin on cytomorphology of broad bean (Vicia faba L.). Jour Saudi Soc Agric Sci 2013; 12:143-46. https://doi.org/10.1016/j.jssas.2012.11.001

38. Irum A, Tabassum S, Qureshi R, Gulfraz M, Anwar P Phytochemical analysis of medicinally important constituents of Teucrium stocksianum Boiss. Pak J Bot 2019; 51(3): 1067-74. https://doi.org/10.30848/PJB2019$\underline{3(17)}$
39. Cruz-Ortega R, Anaya GAL, Ramos L. Effects of allelopathic compounds of corn pollen on respiration and cell division of water melon. J ChemEcol1988; 14(1):71-86 https://doi.org/10.1007/BF01022532

40. Rai PD, Paudel N, Shakya S. R. Cytological effects of leaf extract of Artemisia vulgaris L. on meristematic cells of Allium cepa L.Our Nature 2012;10: 242-48. https://doi.org/ 10.3126/on.v10i1.7787

41. Mohammad FI, El-Ashry ZM. Cytogenetic effect of allelochemicals Brassica nigra L. extracts on Pisum sativum L. World Appl Sci. Journal 2012;20(3):344-53.

42. Talukdar D. Allelopathic effects of Lantana camara L. on Lathyrus sativus L.: Oxidative imbalance and cytogenetic consequences. Allelopathy Journal 2013;31 (1):71-90.

43. FrescuraVDal-Souto, Kuhn AW, Laughinghouse HD, Nicoloso FT, Lopes SJ, Tedesco SB. Evaluation of the allelopathic, genotoxic, and antiproliferative effect of the medicinal species Psychotria brachypoda and Psychotria birotula (Rubiaceae) on the germination and cell division of Eruca sativa (Brassicaceae). Caryologia 2013; 66:138-44. https://doi.org/10.1080/00087114.2013.821832

44. Fonseca VB, Tavares VRdeS, Goncalves VdM, Fritag RA, Bobrowski VL. Allelopathic potential of leaves and flowers extracts of Schinus terebinthifolius Raddi. $\begin{array}{lll}\text { Ceientifica } & \text { 2016; } & \text { 44(1):35-39. }\end{array}$ https://doi.org/10.15361/1984-5529.2016v44n1p35-39

45. Ayeni MJ, Akinyede OA. Effects of Calotropis procera (Ait.) R.Br. leaves on the germination and early growth of soybeans (Glycine max L). J Agric \& Vet Sci 2014; 7(4): 5-9. https://doi.org/10.9790/2380-07420509

46. Lubini G, Fachinetto JM, Launghingouse HD, Paranhos JT, Silva ACF, Tedesco SB. Extracts affecting mitotic division in root-tip meristematic cells. Biologia2008; 63(5): 647-651. https://doi.org/10.2478/s11756-008-0108-x

47. Sharma M, Tandon S, Agarwal V, Bhat KG, Kappadi D, Chandrashekhar $\mathrm{P}$ et al. Evaluation of antibacterial activity of Calotropis gigantea against Streptococucs mutans and Lactobacillus acidophilus: an in vitro comparative study. J Conserv Dentistry 2015; 18(1):457460. https://doi.org/10.4103/0972-0707.168809

48. Abdelmigid HA, Morsi MM. Cytotoxic and molecular aspects of allelopathic effects of leaf residues of Eucalyptus globolus on soyabean (Glycine max). J. Eng \& Biotechnol 2017; 15:297-302. https://doi.org/10.1016/j.jgeb.2017.08.005 